\title{
Influences of Land-Use Dynamics and Surface Water Systems Interactions on Water-Related Infectious Diseases-A Systematic Review
}

\author{
Joshua Ntajal ${ }^{1,2, * \mathbb{D}}$, Timo Falkenberg ${ }^{2,3}$, Thomas Kistemann ${ }^{3}$ and Mariele Evers ${ }^{1}$ \\ 1 Department of Geography, University of Bonn, 53115 Bonn, Germany; mariele.evers@uni-bonn.de \\ 2 Center for Development Research, University of Bonn, 53113 Bonn, Germany; falkenberg@uni-bonn.de \\ 3 GeoHealth Centre, Institute for Hygiene and Public Health, University of Bonn, 53127 Bonn, Germany; \\ thomas.kistemann@ukbonn.de \\ * Correspondence: joshuantajal@uni-bonn.de
}

Received: 30 January 2020; Accepted: 23 February 2020; Published: 26 February 2020

\begin{abstract}
Human interactions with surface water systems, through land-use dynamics, can influence the transmission of infectious water-related diseases. As a result, the aim of our study was to explore and examine the state of scientific evidence on the influences of these interactions on water-related infectious disease outcomes from a global perspective. A systematic review was conducted, using 54 peer-reviewed research articles published between 1995 and August 2019. The study revealed that there has been an increase in the number of publications since 2009; however, few of these publications $(n=6)$ made explicit linkages to the topic. It was found that urban and agricultural land-use changes had relatively high adverse impacts on water quality, due to high concentrations of fecal matter, heavy metals, and nutrients in surface water systems. Water systems were found as the common "vehicle" for infectious disease transmission, which in turn had linkages to sanitation and hygiene conditions. The study found explicit linkages between human-surface water interaction patterns and the transmission of water-based disease. However, weak and complex linkages were found between land-use change and the transmission of water-borne disease, due to multiple pathways and the dynamics of the other determinants of the disease. Therefore, further research studies, using interdisciplinary and transdisciplinary approaches to investigate and enhance a deeper understanding of these complexities and linkages among land use, surface water quality, and water-related infectious diseases, is crucial in developing integrated measures for sustainable water quality monitoring and diseases prevention.
\end{abstract}

Keywords: review study; land-use change; water quality; diarrhea; schistosomiasis; infectious diseases

\section{Introduction}

The emergence of historical civilizations, human settlements, and agricultural and trade activities along rivers, lakes, and deltas, illustrates the spatial distribution of water and its importance to humans [1,2]. Usually, the quality of water from these sources is deteriorated by human activities [2,3]. The status of water resources (quality and quantity) is largely influenced by human activities, such as water abstraction and water pollution, which are partly related to land-use change [4]. Land-use and land-cover change (LULC) influence numerous elements within water systems at diverse spatio-temporal scales [5,6]. LULC within watersheds has effects on stormwater runoff and flooding, which are major processes in the transportation of domestic and industrial effluents, sediments. and nutrients into surface water systems [7-9].

Land use (LU) is generally described as the type of human activities that occur on the land, towards the achievement of socio-economic growth and development $[7,8]$. In urban and peri-urban 
settings, land use is described as the spatial, socio-economic, and institutional usage of the land and its entrenched resources for infrastructure development [7]. Land-use change refers to the modifications or complete conversion of land into another type, due to changes in human activities. In forested and cultivated or vast vegetated areas, land cover (LC) is usually the appropriate term to adopt, as it describes the physical characteristics of a place, e.g., grasses, trees, wetlands, or human artifacts [7]. LULC is influenced by multiple drivers of urban and rural transformation processes, such as population growth, culture, climate change, migration, and politics on diverse levels, which influence the quality (and quantity) of water resources $[7,10]$. In terms of urban transformation, LULC is entwined in the urbanization processes [11].

Urbanization is described as a complex socio-economic, environmental, and societal process, which transforms the built environment through the conversion of rural settlements into urban settlements [11]. Besides the economic and infrastructure development, the urbanization process is perceived as a megatrend of LULC [12]. As reported in the 2018 revision of the World Urbanization Prospects of the United Nations, more than half (55\%) of the world's population lived in urban areas as of 2018 , against $30 \%$ of the urban population in 1950 [11]. It was projected that by 2050 , more than $68 \%$ of the global population will be urban, where the larger portion of the population will be concentrated in Africa (1.2 billion) and Asia (3.3 billion) [11,12]. In low- and middle-income countries, where the rate of urbanization is faster than infrastructure development and spatial land-use planning, challenges with water systems, waste management, sanitation, and hygiene will likely be aggravated [11,12].

Urban surface water systems are increasingly facing stress from pollution in most developing countries in Asia, Africa, and Latin America, as a result of land-use change, lack of wastewater treatment, and poor water quality monitoring [13-15]. Threats to human health, particularly the emergence and spread of water-related infectious diseases (WRID) and sanitation have been the focus of many research studies in South-East Asia and Sub-Saharan Africa; however, such studies focused less on the interactions between LULC and diseases $[13,16,17]$. Water pollution can have detrimental influences on the transmission of WRID [18-20].

A limited number of studies have taken the linkage among LULC, water quality, and WRID into account from an interdisciplinary perspective, in terms of research content and methodology [6,21]. This illustrates the need for comprehensive investigations into the underlying human-water-disease interactions [18,22]. Therefore, there is a need for a systematic review of the literature to assess and consolidate the current scientific evidence on the influences of human-surface water interactions on WRID outcomes.

\section{The Conceptual Linkages among Land Use, Water Quality, and WRID}

\subsection{LULC and Surface Water Quality}

In most urban areas in Asia, Latin America, and Sub-Saharan Africa, floods pose huge challenges to water resources due to poor urban land-use planning [23]. Construction of buildings in wetlands and choking of drainage systems with wastes increases the likelihood of river and flash floods, given extreme rainfall and stormwater flow [24]. Watersheds with a large percentage of developed urban areas and agriculture fields, tend to have higher contaminant concentrations [24]. Expansion of human settlements, as well as the expansion of cultivated areas into natural forest and grasslands near river catchments for drinking-water, are risky land-cover changes $[25,26]$. Conversion of a land cover type into built-up areas, roads, or parking grounds can increase stormwater runoff and the transportation of pollutants into water bodies [14,27].

\subsection{Water-Related Infectious Diseases (WRID)}

According to the Protocol on Water and Health, water-related diseases could be described as "any significant adverse effects on human health, such as death, disability, illness or disorders, caused directly or indirectly by the condition, or changes in the quantity or quality, of any waters" [28] 
(p. 1). The Bradley Classification categorizes WRID into water-borne, water-based, water-washed, and water-related vector-borne diseases [29-31]. Water-borne diseases (e.g., diarrheal diseases) are transmitted via water and occur through the ingestion of water with high fecal pollution. On the other hand, water-washed diseases (hygiene-related) occur due to insufficient water supply for the maintenance of adequate hygiene. The pathogens are transmitted person-to-person through body contact [15,32-34]. Insects, such as mosquitoes, which breed and feed in or near water cause vector-borne diseases (e.g., malaria and dengue). Water-based diseases (e.g., schistosomiasis and Buruli ulcer) are caused by parasites (e.g., worms), which require an aquatic host (e.g., snails) to complete their life cycle [28,35]. In this study, WRID includes all classes of infectious diseases stated above.

\subsection{Influences of Water Quality on WRID}

Pollution of surface water sources can increase the exposure of humans to water-related pathogens [36]. Poor water quality, sanitation, and hygiene are reported as the leading causes of health problems in developing countries [37]. Globally, reports indicate that nearly 15\% of deaths among children below 5 years are linked to diarrheal diseases [38]. The number of reported deaths of cholera to the World Health Organization (WHO) had increased between 2015 and 2017. For example, in 2015, 172,454 cases of cholera and 1304 deaths were reported to the WHO. In 2017, 1,227,391 cases with 5654 deaths were reported to the WHO worldwide [38]. In contrast, 499,447 cases with 2990 deaths were reported in 2018 , indicating a global decrease in the case numbers and deaths of cholera [38]. It was argued that the discrepancies in the reported deaths between 2017 and 2018 was likely an indication of improvements in safe water supply, sanitation, and hygiene behavior, and increased cholera vaccination coverage [38]. However, the distribution of the reported cases in the cholera endemic regions raised concerns about the challenges with the disease surveillance system and fear of implications the disease can have on trade and tourism in countries of such regions [38]. Figure 1 illustrates the transmission pathways of diarrheal diseases, including cholera.

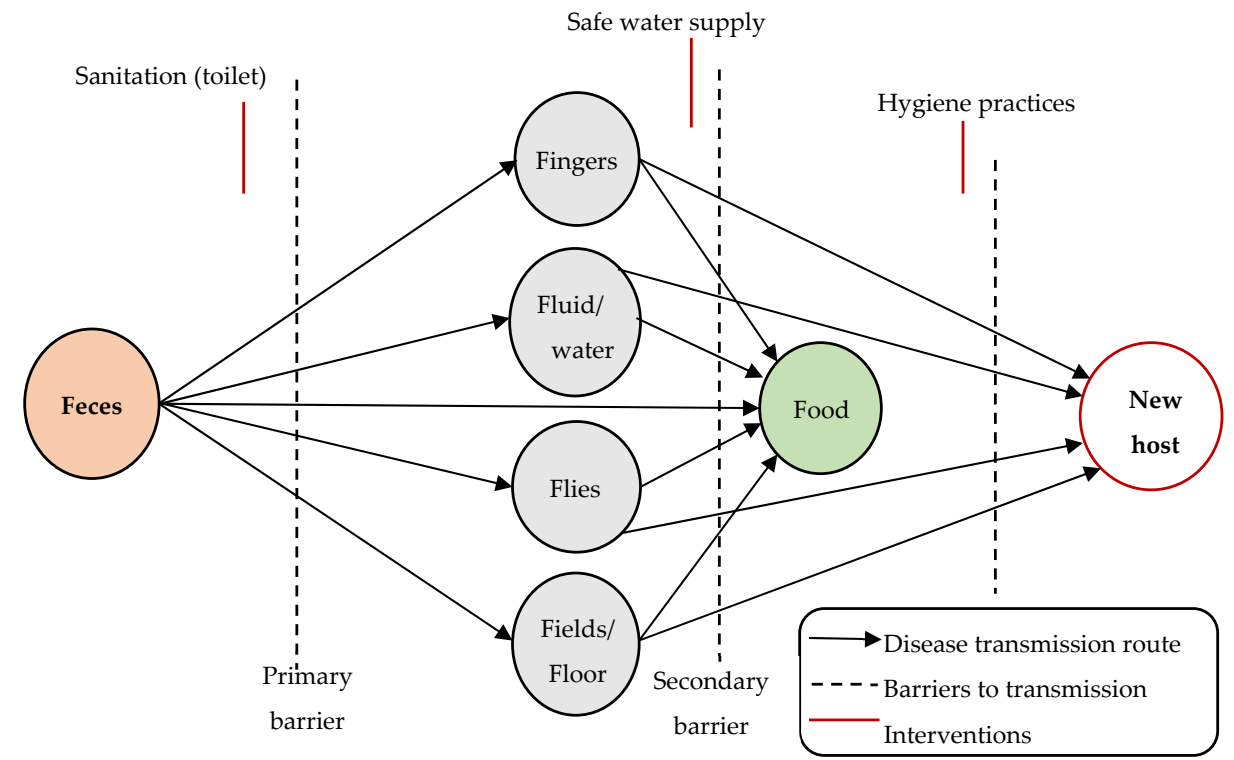

Figure 1. Diarrhea transmission pathways through polluted water sources. Source: Adapted from [39].

Human factors such as sanitation, hygiene, and health-seeking behaviors play major roles in diarrhea transmission, as usually illustrated using the F-Diagram [40]. The F-Diagram illustrates the different transmission pathways through which fecal pathogens are transferred from an infected person to a new host (Figure 1) $[39,41]$. The starting point is the release of fecal pathogens into the environment through open defecation or unimproved sanitation facilities. The transmission occurs through unclean hands (failure to wash hands after using the toilet), polluted drinking water, flies, 
or contaminated food. Consuming food prepared with water from polluted sources or consuming fresh vegetables from irrigated fields exposes households to pathogens [38].

Diarrheal disease transmission pathways in Tanzania, Senegal, Uganda, Ghana, and Nigeria, where recurrent cases of diarrheal diseases are reported, followed the illustrations in the F-diagram [42-44]. Similar examples were reported in poor and water-deprived communities in Pakistan, Iran, Indonesia, India, and Vietnam $[17,31,40,45]$. In most cases, water serves as a vehicle for infectious disease transmission. Land use, in all forms and at all scales, as well as sanitation and hygiene practices are critical underlying risk factors. The importance of the F-Diagram is found in its application in the identification of potential barriers and interventions, which can be used to control and break the cycle of diarrheal disease transmission.

The interactions between humans and surface water systems can have complex linkages to health, through interrelated processes within watersheds [46]. However, the literature reveals that these interactions and their resultant influences on WRID have more often been examined separately without explicit linkages $[6,43]$. To protect water resources, research studies recommended the assessment of land use influences on water quality, taking into consideration residential development and waste disposal amongst others [43,47]. In this review paper, our objective was to explore and examine the state of scientific evidence in this area from a global perspective and identify gaps in knowledge.

\section{Methodology}

In conducting the systematic review, we adopted the "Preferred Reporting Items for Systematic Reviews and Meta-Analyses (PRISMA)" approach [48]. A thorough search of the literature was performed, following the systematic, quantitative, and qualitative assessment approach $[49,50]$. This approach includes (1) identification of the key research question, (2) identification of relevant articles, (3) selection of the relevant articles, (4) charting and tabulating of data, and (5) reporting and summarizing the results. The advantage of this procedure is that it reduces the chances of omitting critical aspects of literature reviews [51]. It was argued that this approach is relatively easy to use and offers more insights than the "traditional narrative" approaches [49]. The approach has been widely adopted in systematic literature review studies $[21,50,52,53]$. In this review, we combined both the systematic quantitative and the "traditional narrative" approaches, as the traditional narrative approach offers the flexibility of extracting common themes from key findings [21,50].

\subsection{Identification of the Key Research Question}

This review study aims to answer the following question: What is the current state of evidence on the interactions between land-use dynamics and surface water systems, and the transmission of WRID? The review scope and the review process were conducted on a global scale.

\subsection{Identification of Relevant Articles}

Prior to the selection of the relevant peer-reviewed articles, a comprehensive search of the scientific literature was conducted, utilizing the online bibliographic databases: Google Scholar, PubMed, Public Library of Science, Science Direct, and Web of Science. We developed an online search query, using a combination of the key terms, concepts, and phrases related to the topic under investigation (land use, land-use change, water quality, sanitation and hygiene, WRID) (see Table 1). We further explored the references of these articles, using the "ancestry" approach (the screening references of other studies for eligibility of inclusion) [52]. Searching and identification of the relevant literature involved a multi-step approach. During the initial search, 1303 articles were retrieved.

Bibliographic information from Google Scholar was extracted using web search engines. The citations of the relevant papers were exported into the Zotero reference management system. If the citation link was unavailable, the PDF file of the paper was imported into Zotero, which automatically extracts the information. The information was double-checked for errors and completeness. 
Table 1. Keywords and syntax used for the literature search.

\begin{tabular}{|c|c|c|c|}
\hline Land use & Water Quality & Infectious WRID & $\begin{array}{l}\text { Combined } \\
\text { Search }\end{array}$ \\
\hline $\begin{array}{l}\text { "land use" OR “land use } \\
\text { change" OR "built-up } \\
\text { areas" OR } \\
\text { “bare-grounds" OR } \\
\text { "cultivated areas" OR } \\
\text { "farm" AND. }\end{array}$ & $\begin{array}{l}\text { “water pollution" OR } \\
\text { "Physicochemical" OR } \\
\text { "fecal pollution" OR } \\
\text { "solid wastes" OR } \\
\text { "wastewater" AND. }\end{array}$ & $\begin{array}{l}\text { "health" OR "water-borne" OR } \\
\text { "water-related" OR "diarrhea" OR } \\
\text { "cholera" OR "fever" OR "malaria" } \\
\text { OR "schistosomiasis" OR “Buruli } \\
\text { ulcer" OR "bacteria" OR "parasite" } \\
\text { OR "pathogen" AND. }\end{array}$ & $\begin{array}{l}\text { "1" AND “2" } \\
\text { AND “3" }\end{array}$ \\
\hline
\end{tabular}

\subsection{Selection of the Relevant Articles: Inclusion and Exclusion Criteria}

The selection of relevant articles was done by a thorough skimming of the peer-reviewed articles between 1995 and August 2019. The papers, which did not have relevant information on land use, water pollution, and WRID were excluded. Similarly, review articles and theses of Ph.D. studies were excluded from the review. Advancement in the literature review was made by reading the abstracts, the key findings, and relevant text of the articles for the final selection of the eligible studies. The selected studies were uploaded on a desktop referencing system for full-text analysis and data extraction. The relevant information and metadata were extracted, tabulated, and tallied for qualitative and quantitative analysis. These included land use, key parameters of water quality, water-related infectious diseases (diarrheal diseases, schistosomiasis, etc.), and the pathways through which LUC influences surface water pollution. The PRISMA diagram, illustrated in Figure 2, summarizes the steps adopted for the selection of eligible research studies.

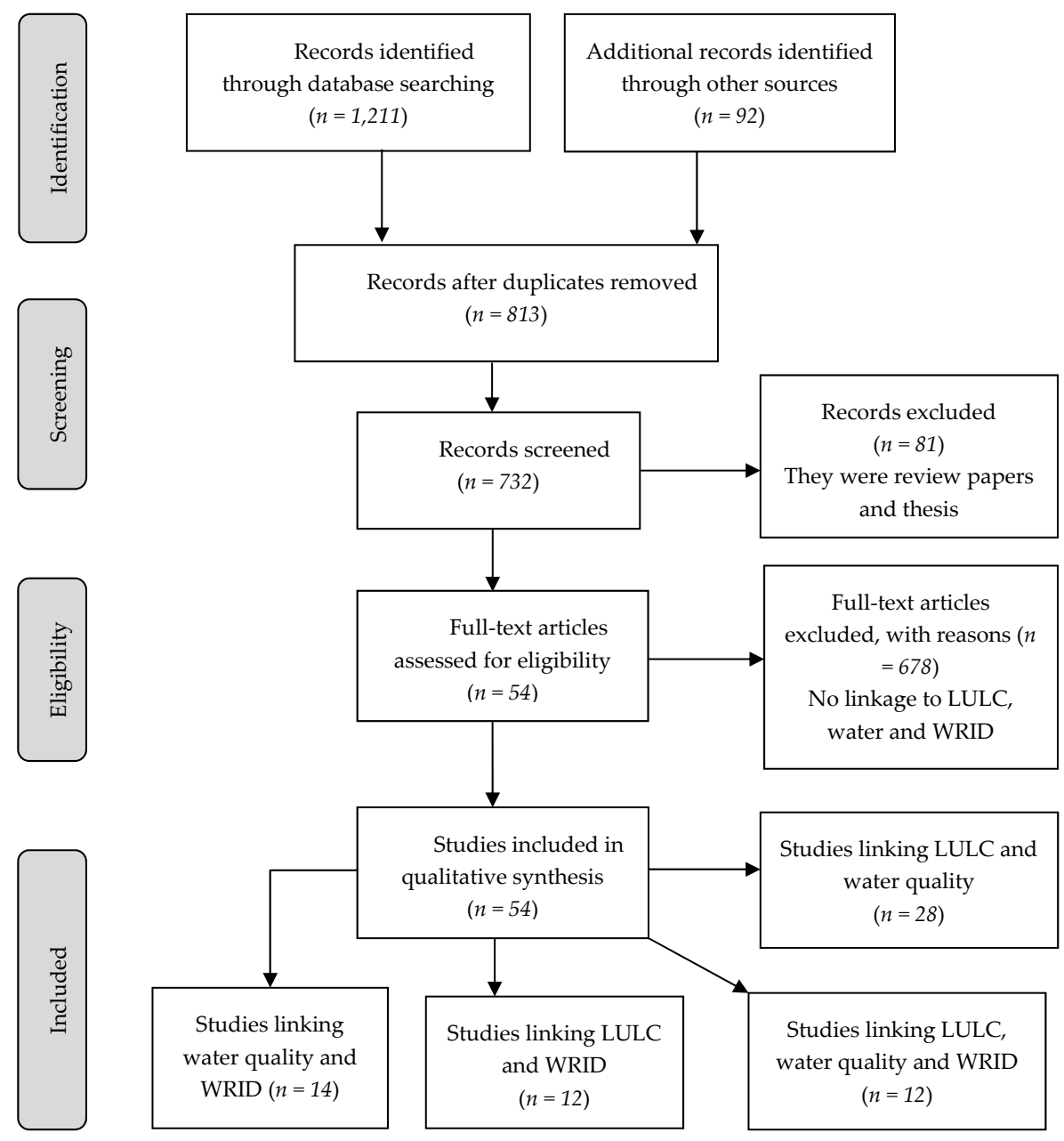

Figure 2. PRISMA flow diagram for the selection of the eligible studies Source: Adapted from [48]. 


\subsection{Charting and Tabulating of Data}

The authors created excel spreadsheets, where data extracted from the selected peer-reviewed articles were listed. These included the names of the authors, the title of the paper, year of publication, country of the study, land use-water interactions, WRID, and summary of key results.

\subsection{Reporting and Summarizing of the Results}

Descriptive statistics were utilized for analyzing and synthesizing data. Regarding content analysis, qualitative and narrative approaches were used in presenting and discussing the results. The results from the descriptive statistics and the spatial distribution of the studies are presented in the following sections in the form of graphs, maps, and tables.

\section{Results}

This section presents the results of 54 peer-reviewed research articles included in this review. These studies were categorized based on the linkages between land use and surface water systems, land use and WRID, surface water pollution and WRID, and influences of land use, surface water quality, and WRID on a global scale. The review considered only original peer-reviewed research studies, which made explicit linkages among land use, surface water, and WRID.

\subsection{Trends in the Scientific Studies on LULC, Surface Water Quality, and WRID}

The review (Figure 3) revealed an increase in the scientific literature on the research problem over the past decade (2009-2019). Scientific studies related to either land use, water quality, or infectious diseases exist since 1995; however, these studies have not made explicit linkages among the key research concepts from a global perspective. It was observed that scientific evidence on the interactions between LUC and surface water quality has increased from 2011 to 2019. This can be linked to the increasing challenges of limited access to clean drinking water, sanitation, and hygiene, which contribute to the outbreak of infectious diseases in the fast-growing urban areas and poor rural communities in developing regions.

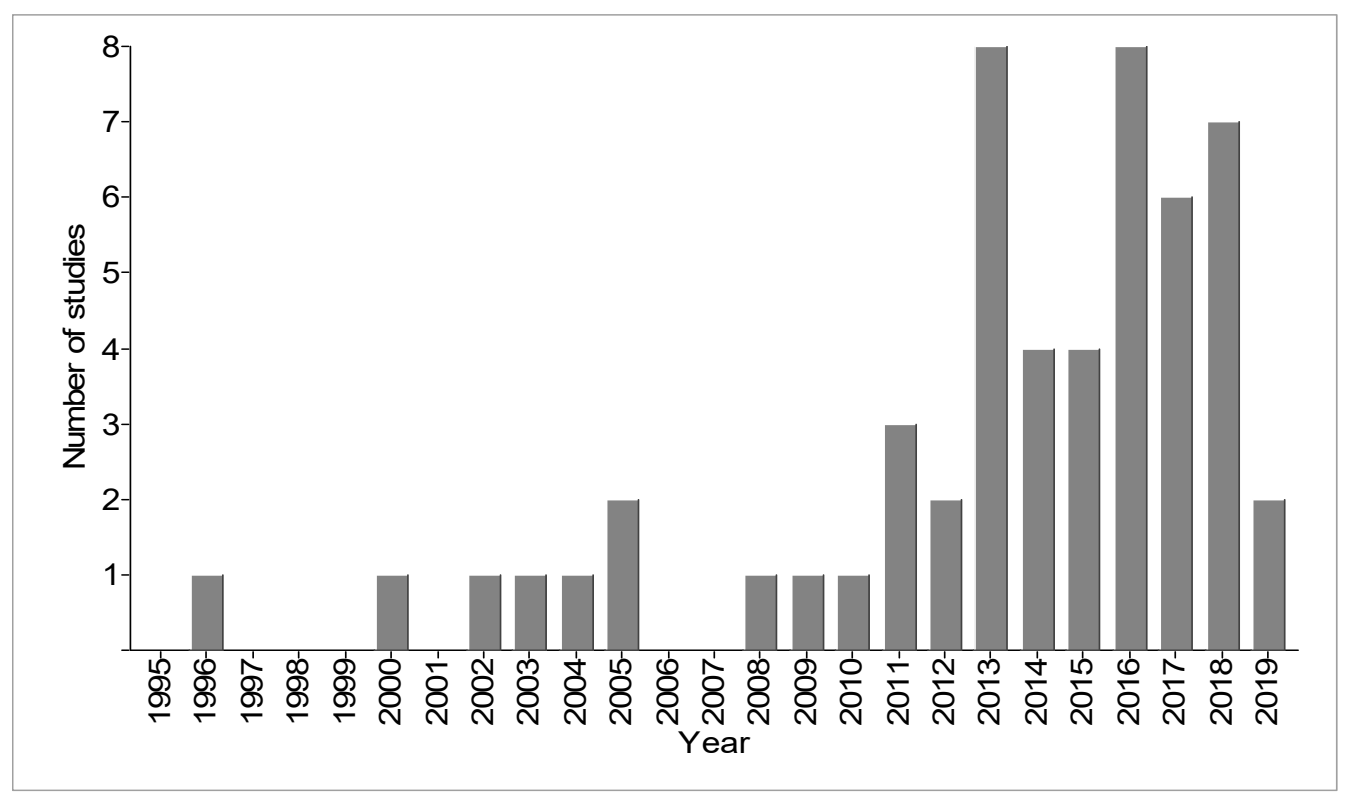

Figure 3. Number of studies between 1995 and August 2019. 


\subsection{Distribution of Studies by Country/region}

The assessment of the literature on the global scale provided a broader perspective about the distribution of scientific studies linking land-use change, surface water quality, and infectious diseases (Figure 4$)$. It was found that $20.37 \%(n=11)$ of studies were conducted in the Peoples Republic of China, while about $11 \%(n=6)$ were conducted in the United States of America and Ghana, respectively. On average, it was observed that a higher number of the included studies were countries classified as developing regions, such as sub-Saharan Africa, Asia, and Latin America, where there is limited potable drinking-water, poor wastes management, poor water quality monitoring, unsustainable agricultural practices, and limited access to funds for scientific research. There are many studies on water quality and diseases; however, these studies lacked explicit linkages to WRID [53,54].

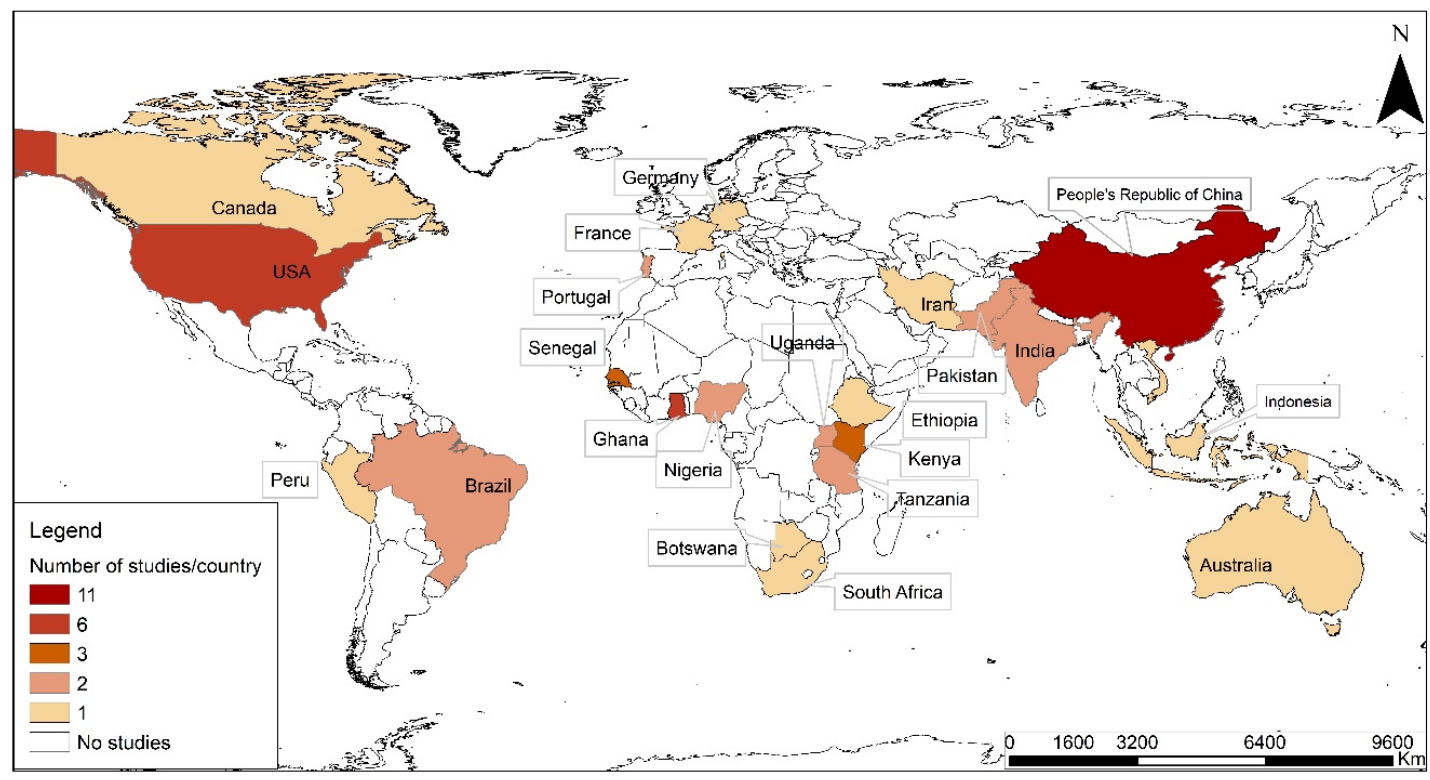

Figure 4. Distribution of reviewed studies by country/region (1995-2019).

\subsection{Land Use and Land Cover Classification}

Land use and land cover are characterized or classified based on the aim of a specific study. However, there are similarities among the various classes [8]. Land-use patterns as described in the various studies were broadly classified into nine (9) classes (Figure 5). It was found that a higher number of studies $(n=28)$ focused on the links between agricultural land-use change, surface water pollution, and the emergence of water-borne disease. These included both point-source and non-point-source pollution of water from cultivated lands and livestock raising sites [55]. Human settlement expansion, including urban sprawl and expansion of peri-urban and rural areas, were factors that resulted in the conversion of natural forestlands, grasslands, and wetland reserves into residential areas [54,56]. Urbanization has formed the center for most land-use studies due to its contribution to the pollution of surface water systems, notably in poor countries, where sanitation and sewage systems were poorly developed [57,58]. It was recorded that land-use change characterized by built-up areas such as urban, peri-urban, and rural residential areas was found in most of the studies $(n=26)$. Similarly, twenty-six studies $(n=26)$ focused on water bodies as a crucial class of land use and land cover. Deforestation $(n=17)$ was found as an equally important land-use change pattern, which influenced the transportation of nutrients, sediments, and other chemical contaminants into surface sources, through stormwater runoff, flooding, and windstorms $[5,59,60]$. 


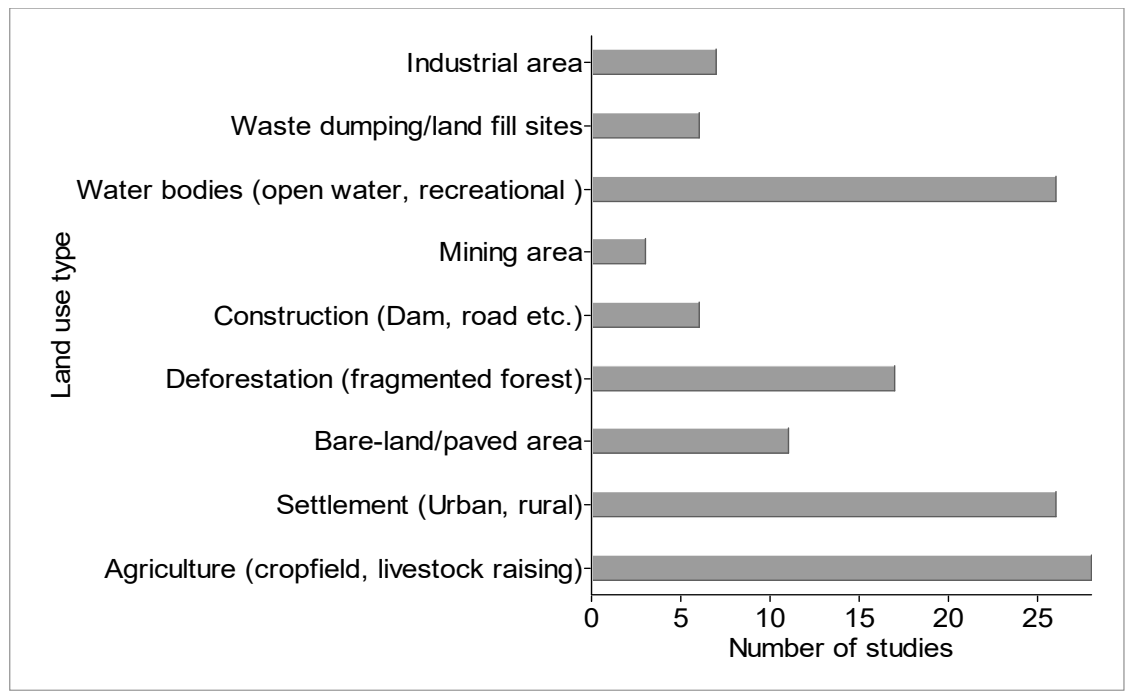

Figure 5. The general classification of land use and land cover.

\subsection{Identified Water-Related Infectious Diseases}

It was found in the reviewed studies that there is a complex link between land use and infectious diseases due to the dynamics involved in the emergence and the transmission of the diseases $[45,57,61]$. A few studies $(n=6)$, which made explicit linkages between land-use change and surface water pollution, identified some common infectious water-related diseases (Figure 6). Relatedly, water-borne diseases appeared in 22 studies in Africa and Asia [61-63]. Schistosomiasis $(n=16)$ was commonly examined as a result of its emergence and transmission through direct human interaction with water (body contact with polluted water and the infected intermediate snail host). Buruli ulcer and hookworm, which were classified as Neglected Tropical Diseases, emerged in studies $(n=5)$ in Africa, with devastating health impacts and economic burden on households [64,65]. The study revealed that the number of studies on schistosomiasis had increased globally between 2013 and 2016 [35,43]. Further, studies on diarrheal diseases such as cholera and dysentery in relation to land use and water quality fluctuated from year to year; however, a steady increase was observed between 2013 and 2018, with a high number of studies in 2017. The number of studies on malaria with explicit linkages to LULC and water quality has not changed over the years, since 2013. Further, there were missing studies in the literature on malaria with links to LULC in 2016 and 2017. It was identified that studies on hookworm were found only in 2016 [66].

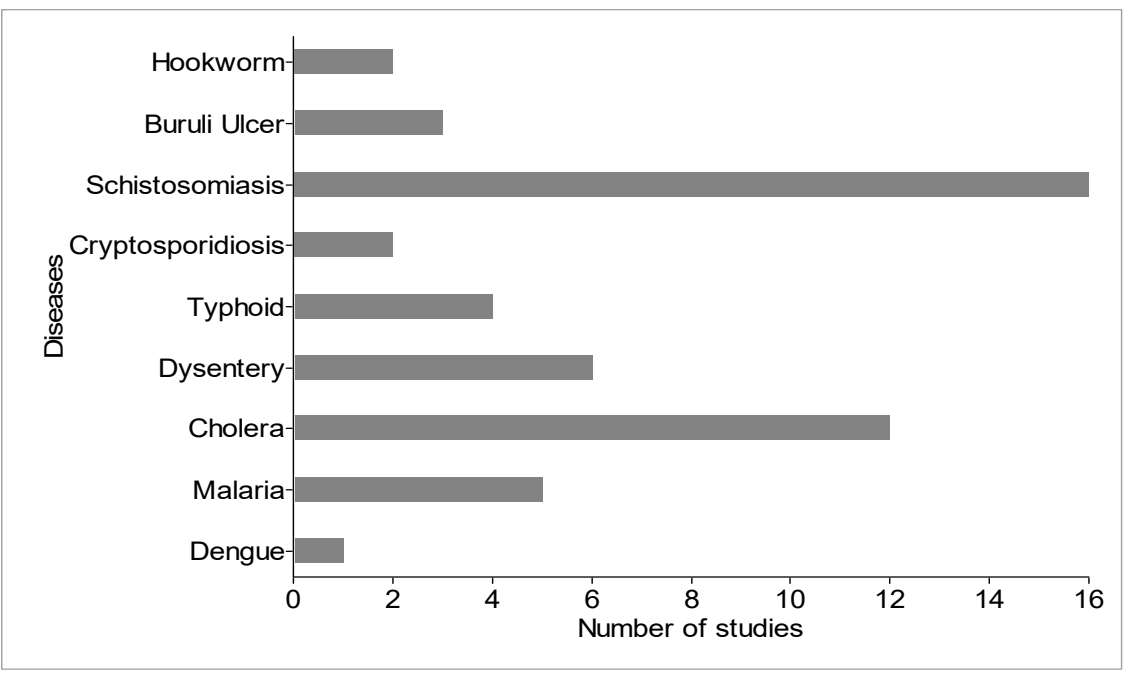

Figure 6. Infectious diseases related to land-use change and surface water quality. 


\subsection{Land-Use Change and Surface Water Pollution Pathways}

The review revealed various mechanisms influencing land-use change and surface water pollution. Water pollution occurred through point-source, non-point-source, and point-of-use [67]. Well-documented processes, such as stormwater runoff, flooding, and direct dumping of domestic and industrial effluents into surface water systems, were identified in the studies as the major water pollution pathways. These mechanisms are summarized in relation to the given land-use classes and water quality parameters (Table 2). Anyona et al. $[45,58]$ reported that deforestation within river catchments exacerbated the process of erosion and increased surface runoff, which facilitated the transport of nutrients (nitrogen and phosphorus) and sediments into water systems. These lead to the siltation of the water channel and reservoirs through sedimentation, as well as eutrophication due to the supply of nutrients from agricultural fields $[5,56,59,68]$. It was identified that fast industrialization in China has resulted in the discharge of organic pollutants into rivers, severely affecting water quality. Examples were the high chemical oxygen demand (COD) found in water bodies in industrial cities such as Anshan, Liaoyang, Fushun, and Shenyang in China [69].

Table 2. Linking land use/land cover and surface water pollution.

\begin{tabular}{|c|c|c|c|}
\hline $\begin{array}{c}\text { Land-Use } \\
\text { Classifications }\end{array}$ & Mechanisms of Water Pollution & $\begin{array}{c}\text { Water Quality } \\
\text { Parameters Tested. }\end{array}$ & Citation \\
\hline $\begin{array}{l}\text { Agriculture (cropland, } \\
\text { livestock raising) }\end{array}$ & $\begin{array}{l}\text { Pollution with sediments and nutrients from } \\
\text { farms, through stormwater runoff and flooding. }\end{array}$ & $\mathrm{pH}, \mathrm{EC}, \mathrm{DO}, \mathrm{N}, \mathrm{K}, \mathrm{TN}, \mathrm{TP}, \mathrm{TSS}$ & {$[8,55,70-72]$} \\
\hline Settlement (Urban, rural) & $\begin{array}{l}\text { Point-source and non-point-source pollution } \\
\text { due to poor sanitation and waste management }\end{array}$ & $\begin{array}{l}\text { Heavy metals, fecal coliform, } \\
\text { E. coli, temperature, }\end{array}$ & {$[8,32,67,73,74]$} \\
\hline $\begin{array}{l}\text { Deforestation } \\
\text { (fragmented forest) }\end{array}$ & $\begin{array}{l}\text { A decrease in vegetation cover exposed water } \\
\text { to extreme heat, led to sedimentation and } \\
\text { eutrophication }\end{array}$ & $\begin{array}{l}\text { Temperature, turbidity, pH, COD, } \\
\text { BOD, DO, TSS, EC heavy metals }\end{array}$ & {$[8,75-77]$} \\
\hline Industrial area & Industrial and domestic effluents pollute water & $\begin{array}{l}\text { Turbidity, } \mathrm{pH}, \mathrm{COD}, \mathrm{BOD}, \\
\text { DO, TSS }\end{array}$ & {$[8,61,78]$} \\
\hline Bare-land/paved area & Pollution of water through stormwater & N, P, fecal coliform, E. coli & {$[79,80]$} \\
\hline $\begin{array}{l}\text { Water bodies (open } \\
\text { water, recreational) }\end{array}$ & Pollution with fecal matter & $\begin{array}{l}\text { E. coli, fecal matter, C. parvum } \\
\text { oocysts, Giardia duodenalis cysts }\end{array}$ & {$[32,35,79,81]$} \\
\hline Mining area & $\begin{array}{l}\text { Point-source pollution through stormwater } \\
\text { runoff from mining areas }\end{array}$ & $\mathrm{N}, \mathrm{P}, \mathrm{COD}, \mathrm{DO}$, heavy metals & {$[74,76,82]$} \\
\hline $\begin{array}{l}\text { Waste dumping/ } \\
\text { landfill sites }\end{array}$ & Wastewater solid waste disposal & EC, pH, DO, Cu, lead & {$[6,73]$} \\
\hline
\end{tabular}

\subsection{Water Quality Parameters and the Potential Water-Related Infectious Diseases}

It is often difficult to understand the complete disease ecology and the underlying causes of exposure, due to the complexities involved in the transmission dynamics of pathogens. It is worth noting that studies $(n=14)$ have established some level of agreement in the identification and characterization of some potential WRID, which are commonly associated with changes in water quality parameters (Table 3) [75]. It was reported that changes in water temperature, turbidity, and $\mathrm{pH}$ influenced the survival and abundance of the Anopheles mosquito, which transmits malaria [75]. Relatedly, it was recorded that higher concentrations of E. coli and fecal matter in drinking-water were associated with diarrheal diseases (cholera and dysentery) [45,58]. In the same fashion, schistosomiasis was associated with polluted surface water systems in Kenya and Senegal, due to the presence of fecal matter in the water, which promotes the survival of the intermediate snail host [35,76,83-86]. 
Table 3. Summary of water quality parameters and the potential infectious diseases.

\begin{tabular}{ccc}
\hline Water Quality Parameters & Diseases & Sources \\
\hline Temperature, turbidity, $\mathrm{pH}$ & Dengue & {$[75]$} \\
\hline Temperature & Malaria & {$[59,75,87]$} \\
\hline E. coli, fecal coliform & Cholera & {$[45,61,62,81,88]$} \\
\hline E. coli, fecal coliform, turbidity, pH & Dysentery & {$[61,62,89]$} \\
\hline E. coli, fecal coliform & Typhoid fever & {$[61,62]$} \\
\hline E. coli, fecal coliform, BOD, temperature, DO & Cryptosporidiosis & {$[70,81]$} \\
\hline Fecal coliform & Schistosomiasis & {$[76,77,83,85,90-92]$} \\
\hline E. coli, fecal coliform, temperature, turbidity & Buruli ulcer & {$[85]$} \\
\hline E. coli, fecal coliform, temperature, DO, BOD, TSS, turbidity & Hookworm & {$[92]$} \\
\hline pH = Potential of Hydrogen; DO = Dissolved Oxygen; BOD & $=$ Biochemical Oxygen Demand; TSS = Total \\
Dissolved Solid. & &
\end{tabular}

\subsection{Studies Linking Land Use, Water, and Major WRID}

The reviewed literature revealed that a few studies $(n=6)$ highlighted explicit linkages among land-use change, surface water quality, and WRID as mentioned above. These studies were found in SSA $(n=3)$, Europe $(n=2)$, and India $(n=1)$, with a special focus on diarrheal diseases and neglected tropical diseases (i.e., schistosomiasis and Buruli ulcer). This was due to the dynamics and the multiple pathways involved in the transmission of infectious diseases, as well as the complex interrelated factors such as an individual's perception of diseases, access to sanitation and hygiene, and consistent and adequate supply of potable water $[43,55,62,64,93]$. These factors do not have well established direct links with land-use change, as in the case of changes in water quality [55,64]. A combination of interactions among various types of LULC was found to have differential effects on specific water quality parameters and WRID $[43,94]$. A summary of these interactions and the key results highlighted in the corresponding countries are presented in Table 4.

Table 4. Combined influences of land-use and land-cover (LULC) types on water quality and water-related infectious diseases (WRID).

\begin{tabular}{|c|c|c|c|c|c|}
\hline LULC & $\begin{array}{l}\text { Water Quality } \\
\text { Parameters }\end{array}$ & WRID & Summary Of Key Findings & Country & Source \\
\hline $\begin{array}{l}\text { Cultivated lands, } \\
\text { swamp, forest, } \\
\text { open water }\end{array}$ & Temperature & Malaria & $\begin{array}{l}\text { Replacement of natural swamp vegetation } \\
\text { with irrigated rice and vegetable farms led to } \\
\text { an increase in temperature and breeding of } \\
\text { Anopheles mosquitos. LULC also reduced } \\
\text { the breeding of mosquito. }\end{array}$ & Uganda & {$[75,95]$} \\
\hline $\begin{array}{l}\text { Dam construction, } \\
\text { streamside pool, } \\
\text { swamps }\end{array}$ & $\begin{array}{l}\text { Temperature, } \\
\text { turbidity, DO, EC, pH }\end{array}$ & Schistosomiasis & $\begin{array}{l}\text { The distribution of the intermediate snails } \\
\text { varied with the variation in vegetation cover, } \\
\text { turbidity, and } \mathrm{pH} \text { of water and soil. }\end{array}$ & Tanzania & {$[76,91]$} \\
\hline $\begin{array}{l}\text { Cropland, forest, } \\
\text { urban area, water } \\
\text { bodies }\end{array}$ & $\begin{array}{l}\text { Cryptosporidium } \\
\text { parvum oocysts, } \\
\text { Giardia duodenalis } \\
\text { cysts, E. coli. }\end{array}$ & Cholera & $\begin{array}{l}\text { Pollution of surface water with C. parvum } \\
\text { and G. duodenalis, due to fecal pollution from } \\
\text { wastewater treatment plants and croplands. }\end{array}$ & France & [81] \\
\hline $\begin{array}{l}\text { Croplands, } \\
\text { recreational waters }\end{array}$ & Fecal coliform & Schistosomiasis & $\begin{array}{l}\text { Recreational activity was the major exposure } \\
\text { and risk factor of schistosomiasis } \\
\text { transmission }\end{array}$ & Ghana & {$[35,90]$} \\
\hline
\end{tabular}

$\mathrm{pH}=$ Potential of Hydrogen; EC = Electro Conductivity; $\mathrm{DO}=$ Dissolved Oxygen; COD = Chemical Oxygen

Demand; BOD = Biochemical Oxygen Demand. 


\section{Discussion}

The study identified various linkages between land-use dynamics and surface water quality, and the consequent influences on WRID in different countries across the globe. This allowed the categorization of land-use and land-cover types into various classes, the identification of water quality parameters, and the relevant WRID. Several research studies have demonstrated the influence of land use on E. coli concentration in drinking-water. For example, Marale et al. [96] reported that an increase in E. coli concentration downstream of the River Indrayani in India was linked to land use in communities located upstream of the river.

Similarly, during winter, van der Hoven et al. [6] identified that the levels of E. coli, EC, DO, and TDS in the Klein Jukskei River were beyond the recommended drinking-water standards in sections of the river close to industrial and informal settlements in South Africa. This was attributed to the upstream discharge of domestic and industrial effluents into the river. Similar results were found in Ghana, Senegal, Indonesia, and Iran [27,63,80,83].

The influence of rainfall and stormwater runoff during winter and summer are crucial pathways of water pollution. The study identified a positive relationship between urban floods and E. coli concentration in flood retention ponds in Botswana [88]. Agricultural land use, such as the cultivation of crops, was linked to an increase in $\mathrm{N}$ and $\mathrm{P}$ in the Fuxian Lake in China [56]. This led to eutrophication and decreased in DO in the lake [56]. In addition, a significant negative relationship was found between forested areas and the amount of ammonia, N, and COD in the Fuxian Lake [41,56]. This illustrated the influences of forestland cover on the rate of stormwater runoff and the transportation of parent materials and nutrients into water systems.

It is worth noting that the various linkages between LULC and surface water quality and the resultant influences on the transmission of infectious diseases were identified; however, the studies focused entirely on the negative aspects of land-use change. The potential positive influences of LUC on water quality and disease ecology was found missing in the literature $[21,53,54,56,59]$. This indicates a potential direction for future research investigations to explore the positive influences of LUC on water quality at different scales in relation to WRID ecology [7]. It was also observed that LULC classification studies oversimplified the concept of LU and did not provide adequate information on LU characteristics at a finer resolution. For example, cultural and recreational aspects of land use were not included in the classification of LULC. These types of LU will likely aid the investigations on human-water interactions and disease outcomes.

\subsection{Influences of Water Quality on WRID}

Water plays a major role in the emergence and transmission of infectious diseases, through direct and indirect pathways [81]. In 2017, flooding in Botswana resulted in an increased concentration of fecal coliforms in the downstream sections of the Chobe River, which contributed to an increase in reported cases of diarrheal diseases by $16.7 \%$ with a four weeks lag among children under five years [88]. Areas with high population density, frequent flooding, bare-soils, and built-up areas were linked to higher reported cases of cholera and typhoid in Semarang City in Indonesia [27]. A significant positive relationship between limited access to potable water and sanitation infrastructure and diarrhea morbidity was observed in 2015 in Accra, Ghana [97].

In addition, the reviewed studies revealed that most direct interactions between humans and water, which resulted in water-based disease outbreaks, were through human skin contacts with polluted water $[35,43,83]$. Relatedly, the probability of being infected depends on the frequency and patterns of human-water contacts. Helminthic diseases, such as schistosomiasis, hookworm, and Buruli ulcer, are classical examples of diseases transmitted through direct contact with polluted water, soil, and infested snail hosts $[71,75,86]$. Lack of sanitation and hygiene facilities compelled households in remote communities in Tanzania to practice open defecation in and around water bodies, which resulted in high levels of fecal coliform concentration in the water and increased the survival rate of the intermediate snail host of Schistosoma haematobium [91]. It was argued that differences in the 
spatial distribution of S. haematobium are influenced by the spatial connectedness of land-use types, water pollution patterns, and risk and exposure factors [92].

\subsection{Directions for Further Research}

This review study has deepened our understanding of the interactions and the linkages among land use, surface water systems, and the transmission of WRID. It provided credible grounds for identifying the gaps in knowledge and scientific evidence on these linkages. In regions such as sub-Saharan Africa, South Asia, and the Middle East, areas which the WHO [38] reported as the hotspots of WRID, interdisciplinary studies exploring the influences of land use and water quality interactions on WRID outcomes has not been comprehensively explored. Therefore, the adoption of multidisciplinary, interdisciplinary, and transdisciplinary research perspectives is required to deepen the understanding of the LULC, water, and WRID nexus. The understanding of the disease ecology extends beyond a single discipline. Systems thinking and complex network frameworks can be adapted to identify the interactions and linkages among the various drivers of LULC and water pollution. Systems thinking and network analysis, employing mind-mapping approaches such as "Driving forces-Pressure-State-Impacts-Response" frameworks and Multi-Criterial Decision Analysis are recommended for structuring and characterizing the interactions.

\subsection{Limitations}

The review study depended mainly on peer-reviewed papers that were published in the English language, and it was considered as a major limitation. Many peer-reviewed papers in French, Spanish, and Portuguese were retrieved from the literature but were not considered in the review, due to the language barrier. It is likely that such papers contain vital information and data, which could be of immense importance to our review. In addition, the review focused on studies, which made explicit linkages to LULC, surface water, and WRID. There were other important studies, which made significant contributions to scientific research but focused on either land-use change, surface water systems, or only WRID. The exclusion of such studies from the review was found as a limitation. Relatedly, the review strictly considered studies that focused on only surface water systems. Studies that made linkages to groundwater sources, such as boreholes and wells, as well as rainwater harvesting, were excluded from this review.

\section{Conclusions}

The review study explored the current state of scientific evidence on the influences of land-use dynamics and surface water systems interactions on WRID. There has been an increase in scientific research on LULC and WRID globally. LULC types have differential impacts on water quality, especially agricultural land use and human settlement areas, where there is poor water quality monitoring and land-use planning. There are linkages between land-use dynamics and WRID outcomes; however, these linkages are relatively complex and weak. On the other hand, there is an explicit linkage between water quality and water-borne diseases with multiple transmission pathways. Human-water interactions have influences on WRID; however, other determinants of health and exposure factors, such as an individual's or community's perception of diseases and health-seeking behaviors, play a major role in the transmissions of WRID. This was an indication of a lack of interdisciplinary and transdisciplinary research collaborations on LULC and WRID.

Author Contributions: Conceptualization, J.N., M.E. and T.F.; methodology, J.N., and T.F.; software, J.N.; validation, M.E., T.K., and T.F.; formal analysis, J.N.; investigation, J.N., and T.F.; resources, T.F.; data curation, J.N.; writing - original draft preparation, J.N.; writing—review and editing, M.E., T.F., and T.K.; visualization, J.N.; supervision, M.E., T.F., and T.K.; project administration, T.F., and T.K.; funding acquisition, T.F., and T.K. All authors have read and agreed to the published version of the manuscript.

Funding: This study was funded by the Ministry of Culture and Science, North Rhine-Westphalia, Germany, though the Forschungskolleg "One Health and Urban Transformation". 
Conflicts of Interest: The authors declare no conflict of interest.

\section{References}

1. Adedire, F.M. Differentials in Metropolitanisation Trends in Lagos Peri-Urban Settlements. J. Sustain. Dev. 2017, 10, 14. [CrossRef]

2. Briassoulis, H. Analysis of Land Use Change: Theoretical and Modeling Approaches; Chapter on; Regional Research Institute, West Virginia University: Morgantown, WV, USA, 2005.

3. Dwarakish, G.S.; Ganasri, B.P.; De Stefano, L. Impact of land use change on hydrological systems: A review of current modeling approaches. Gis Appl. Int. J. Earth Sci. Eng. Ed. Aquat. Procedia Ms. B.P. Dwarakish Ganasri Cogent Geosci. 2015, 1, 1115691. [CrossRef]

4. Serpa, D.; Nunes, J.P.; Keizer, J.J.; Abrantes, N. Impacts of climate and land use changes on the water quality of a small Mediterranean catchment with intensive viticulture. Environ. Pollut. 2017, 224, 454-465. [CrossRef] [PubMed]

5. Ding, J.; Jiang, Y.; Liu, Q.; Hou, Z.; Liao, J.; Fu, L.; Peng, Q. Influences of the land use pattern on water quality in low-order streams of the Dongiiang River basin, China: A multi-scale analysis. Sci. Total Environ. 2016, 551, 205-216. [CrossRef] [PubMed]

6. van der Hoven, C.; Ubomba-Jaswa, E.; van der Merwe, B.; Loubser, M.; Abia, A.L.K. The impact of various land uses on the microbial and physicochemical quality of surface water bodies in developing countries: Prioritisation of water resources management areas. Environ. Nanotechnol. Monit. Manag. 2017, 8, 280-289. [CrossRef]

7. Henderson, L.; Mahoney, C.; Mcclelland, C.; Myers, A. The Effect of Land Use and Land Cover on Water Quality in Urban Environments, Natural Resources and Environmental Sciences; Kansas State University: Manhattan, KS, USA, 2014.

8. Wilson, C.O. Land use/land cover water quality nexus: Quantifying anthropogenic influences on surface water quality. Environ. Monit. Assess. 2015, 187, 424. [CrossRef]

9. Miller, J.D.; Hutchins, M. The impacts of urbanisation and climate change on urban flooding and urban water quality: A review of the evidence concerning the United Kingdom. J. Hydrol. Reg. Stud. 2017, 12, 345-362. [CrossRef]

10. Kleemann, J.; Inkoom, J.N.; Thiel, M.; Shankar, S.; Lautenbach, S.; Fürst, C. Peri-urban land use pattern and its relation to land use planning in Ghana, West Africa. Landsc. Urban Plan. 2017, 165, 280-294. [CrossRef]

11. United Nations; Department of Economic and Social Affairs; Population Division. World Urbanization Prospects: The 2018 Revision (ST/ESA/SER.A/420); United Nations: New York, NY, USA, 2019; ISBN 978-92-1-148319-2.

12. Gerten, C.; Fina, S.; Rusche, K. The Sprawling Planet: Simplifying the Measurement of Global Urbanization Trends. Front. Environ. Sci. 2019, 7, 140. [CrossRef]

13. Schwarzenbach, R.P.; Egli, T.; Hofstetter, T.; von Gunten, U.; Wehrli, B. Global Water Pollution and Human Health. Annu. Rev. Environ. Resour. 2010, 35, 109-136. [CrossRef]

14. Monney, I. Urbanization and Pollution of Surface Water Resources in the Two Largest Cities in Ghana. Int. J. Environ. Monit. Anal. 2013, 1, 279. [CrossRef]

15. Rietveld, L.C.; Siri, J.G.; Chakravarty, I.; Arsénio, A.M.; Biswas, R.; Chatterjee, A. Improving health in cities through systems approaches for urban water management. Environ. Health A Glob. Access Sci. Source 2016, 15, S31. [CrossRef] [PubMed]

16. Kamba, F.; Sangija, F.; Wei, S. Impact of water pollution on human health in the Central African Republic. Adv. Soc. Sci. Res. J. 2016, 3. [CrossRef]

17. Ahmed, A.; Shafique, I. Perception of household in regards to water pollution: An empirical evidence from Pakistan. Environ. Sci. Pollut. Res. 2019, 26, 8543-8551. [CrossRef]

18. United Nations Water. Towards a Worldwide Assessment of Freshwater Quality: A UN-Water Analytical Brief; UN-Water: Geneva, Switzerland, 2016; pp. 1-36.

19. Mackinnon, E.; Ayah, R.; Taylor, R.; Owor, M.; Ssempebwa, J.; Olago, L.D.; Kubalako, R.; Dia, A.T.; Gaye, C.C.; Campos, L.; et al. 21st century research in urban WASH and health in sub-Saharan Africa: Methods and outcomes in transition. Int. J. Environ. Health Res. 2019, 29, 457-478. [CrossRef]

20. Mari, L.; Casagrandi, R.; Rinaldo, A.; Gatto, M. Epidemicity thresholds for water-borne and water-related diseases. J. Biol. 2018, 447, 126-138. [CrossRef] 
21. Mastel, M.; Bussalleu, A.; Paz-Soldan, V.A.; Salmon-Mulanovixh, G.; Valdes-Vaelasquez, A.; Hartinger, S.M. Critical linkages between land use change and human health in the Amazon region: A scoping review. PLoS Negl. TROP. Dis. 2018, 13, e0196414. [CrossRef]

22. Lalande, N.; Cernesson, F.; Decherf, A.; Tournoud, M.G. Implementing the DPSIR framework to link water quality of rivers to land use: Methodological issues and preliminary field test. Int. J. River Basin Manag. 2014, 12, 201-217. [CrossRef]

23. Rain, D.; Engstrom, R.; Ludlow, C.; Antos, S. Accra Ghana: A City Vulnerable to Flooding and Drought-Induced Migration. Case study prepared for Cities and Climate Change: Global Report on Human Settlements, 2011. Available online: http://www.unhabitat.org/grhs/2011 (accessed on 26 February 2020).

24. Hwang, S.-A.; Hwang, S.-J.; Park, S.-R.; Lee, S.-W. Examining the Relationships between Watershed Urban Land Use and Stream Water Quality Using Linear and Generalized Additive Models. Water 2016, 8, 155. [CrossRef]

25. Barton, H. Land use planning and health and well-being. Land Use Policy 2009, 26, 115-123. [CrossRef]

26. Gentry-Shields, J.; Bartram, J. Human health and the water environment: Using the DPSEEA framework to identify the driving forces of disease. Sci. Total Environ. 2014, 468, 306-314. [CrossRef] [PubMed]

27. Deilami, K.; Hayes, J.F.; McGree, J.; Goonetilleke, A. Application of landscape epidemiology to assess potential public health risk due to poor sanitation. J. Environ. Manag. 2017, 192, 124-133. [CrossRef] [PubMed]

28. Kulinkina, V.A.; Shinee, E.; Rafael, B.; Herrador, G.; Nygård, K.; Schmoll, O. The situation of water-related infectious diseases in the pan-European region; World Health Organization: Geneva, Switzerland, 2016; p. 42. ISBN 9789289052023.

29. Guidelines for drinking water quality. In Managing Chemical Hazards in Drinking-Water; World Health Organization: Geneva, Switzerland, 2011; pp. 145-196.

30. White, G.; Bradley, D.; White, A. Reproduced by permission of The University of Chicago Press, \# 1972. Bull. World Health Organ. 1972, 80, 63-73.

31. Kulinkina, V.A.; Mohan, V.R.; Francis, M.R.; Kattula, D.; Sarkar, R.; Plummer, J.D.; Ward, H.; Kang, G.; Balraj, V.; Naumova, E.N. Seasonality of water quality and diarrheal disease counts in urban and rural settings in south India. Sci. Rep. 2016, 6, 20521. [CrossRef]

32. Daly, E.; Kolotelo, P.; Schang, C.; Osborne, C.A.; Coleman, R.; Deletic, A.; Mccarthy, D.T. Escherichia coli concentrations and loads in an urbanised catchment: The Yarra River, Australia. J. Hydrol. 2013, 497, 51-61. [CrossRef]

33. Gara, T.; Fengting, L.; Nhapi, I.; Makate, C.; Gumindoga, W. Health Safety of Drinking Water Supplied in Africa: A Closer Look Using Applicable Water-Quality Standards as a Measure. Expo. Health 2017, 10, 1-12. [CrossRef]

34. Mondal, D.; Ganguli, B.; Sen Roy, S.; Halder, B.; Banerjee, N.; Banerjee, M.; Samanta, M.; Giri, A.K.; Polya, D.A. Diarrhoeal health risks attributable to water-borne-pathogens in arsenic-mitigated drinking water in west Bengal are largely independent of the microbiological quality of the supplied water. Water 2014, 6, 1100-1117. [CrossRef]

35. Nyarko, R.; Torpey, K.; Ankomah, A. Schistosoma haematobium, Plasmodium falciparum infection and anaemia in children in Accra, Ghana. Trop. Dis. Travel Med. Vaccines 2018, 4, 3. [CrossRef]

36. Previsich, N.; Narayanan, A.; Fleury, M.D. One Health, Climate Change and Water Related Issues: A Canadian Public Health Perspective, Global Bioethics. Taylor Fr. Group 2017, 7462. [CrossRef]

37. Clasen, T.; Pruss-ustun, A.; Mathers, C.D.; Cumming, O.; Cairncross, S.; John, M. Estimating the impact of unsafe water, sanitation and hygiene on the global burden of disease: Evolving and alternative methods. Trop. Med. Int. Health 2014, 19, 884-893. [CrossRef]

38. Cholera. Available online: https://www.who.int/news-room/fact-sheets/detail/cholera (accessed on 21 February 2020).

39. Wagner, E.G.; Lanoix, J.N. Excreta Disposal for Rural Areas and Small Communities; World Organization Monograph series; no. 39; World Health Organization: Geneva, Switzerland, 1958; p. 187.

40. Falkenberg, T.; Saxena, D.; Kistemann, T. Impact of Wastewater-Irrigation on In-Household Water Contamination. A Cohort Study Among Urban Farmers in Ahmedabad, India Science of the Total Environment. Available online: https://doi.org/10.1016/j.scitotenv.2018.05.117 (accessed on 26 February 2019).

41. Water1st International F-Diagram. Available online: http://water1st.org/problem/f-diagram/ (accessed on 10 December 2019). 
42. Forstinus, N.O.; Ikechukwu, N.E.; Emenike, M.P.; Christiana, A.O. Water and Waterborne Diseases: A Review. Int. J. Trop. Dis. Health 2016, 12, 1-14. [CrossRef]

43. Anthonj, C.; Diekkrüger, B.; Borgemeister, C. Thomas Kistemann Health risk perceptions and local knowledge of water-related infectious disease exposure among Kenyan wetland communities. Int. J. Hyg. Environ. Health 2019, 222, 34-48. [CrossRef] [PubMed]

44. Soller, J.A.; Schoen, M.E.; Varghese, A.; Ichida, A.M.; Boehm, A.B.; Eftim, S.; Ashbolt, N.J.; Ravenscroft, J.E. Human health risk implications of multiple sources of faecal indicator bacteria in a recreational waterbody. Water Res. 2014, 66, 254-264. [CrossRef] [PubMed]

45. Ahmed, B.; Nafees, M.; Baig, S.A. Assessment of Drinking Water Quality and Water Born Diseases in Post Flood Scenario in District Swat, Pakistan Sustainable Water Sanitation Health and Development Program; World Health Organization (WHO): Abbottabad, Pakistan, 2016; Volume 34, pp. 1238-1242.

46. Vrebos, D.; Beauchard, O.; Meire, P. Science of the Total Environment The impact of land use and spatial mediated processes on the water quality in a river system. Sci. Total Environ. 2017, 601, 365-373. [CrossRef]

47. Näschen, K.; Diekkrüger, B.; Leemhuis, C.; Steinbach, S.; Seregina, L.S.; Thonfeld, F.; van der Linden, R. Hydrological modeling in data-scarce catchments: The Kilombero floodplain in Tanzania. Water 2018, 10, 599. [CrossRef]

48. Moher, D.; Liberati, A.; Tetzlaff, J.; Altman, D.G. Preferred Reporting Items for Systematic Reviews and Meta-Analyses: The PRISMA Statement. PLoS Med. 2009, 6, 6. [CrossRef]

49. Pickering, C.; Byrne, J. The benefits of publishing systematic quantitative literature reviews for PhD candidates and other early-career researchers. Sage 2014, 33, 534-548. [CrossRef]

50. Gottdenker, N.L.; Streicker, D.G.; Faust, C.L.; Carroll, C.R. Anthropogenic Land Use Change and Infectious Diseases: A Review of the Evidence. EcoHealth 2014, 11, 619-632. [CrossRef]

51. Arksey, H.; O'Malley, L. Scoping studies: Towards a methodological framework Scoping Studies: Towards a Methodological Framework. Int. J. Soc. Res. Methodol. 2005, 8, 19-32. [CrossRef]

52. Wright, J.A.; Gundry, S.; Wright, J.; Conroy, R. A systematic review of the health outcomes related to household water quality in developing countries household water quality in developing countries. J. Water Health 2004, 2, 1-13.

53. Cui, H.; Zhou, X.; Guo, M.; Wu, W. Land use change and its effects on water quality in typical inland lake of arid area in China. J. Environ. Biol. 2016, 37, 603-609. [PubMed]

54. Wijesiri, B.; Deilami, K.; Goonetilleke, A. Evaluating the relationship between temporal changes in land use and resulting water quality. Environ. Pollut. 2018, 234, 480-486. [CrossRef] [PubMed]

55. Ribolzi, O.; Cuny, J.; Sengsoulichanh, P.; Mousquès, C.; Soulileuth, B.; Pierret, A.; Huon, S.; Sengtaheuanghoung, O. Land use and water quality along a mekong tributary in Northern Lao P.D.R. Environ. Manag. 2011, 47, 291-302. [CrossRef] [PubMed]

56. Dai, X.; Zhou, Y.; Ma, W.; Zhou, L. Influence of spatial variation in land-use patterns and topography on water quality of the rivers inflowing to Fuxian Lake, a large deep lake in the plateau of southwestern China. Ecol. Eng. 2017, 99, 417-428. [CrossRef]

57. Lambin, E.F.; Tran, A.; Vanwambeke, S.O.; Linard, C.; Soti, V. Pathogenic landscapes: Interactions between land, people, disease vectors, and their animal hosts. Int. J. Health Geogr. 2010, 9, 1-13. [CrossRef] [PubMed]

58. Saravanan, V.S. Urbanizing diseases: Contested institutional terrain of water- and vector-borne diseases in Ahmedabad, India. Water Int. 2013, 38, 875-887. [CrossRef]

59. Patz, J.A.; Daszak, P.; Tabor, G.M.; Aguirre, A.A.; Pearl, M.; Epstein, J.; Wolfe, N.D.; Kilpatrick, A.M.; Foufopoulos, J.; Molyneux, D.; et al. Unhealthy landscapes: Policy recommendations on land use change and infectious disease emergence. Environ. Health Perspect. 2004, 112, 1092-1098. [CrossRef]

60. Meneses, B.M.; Reis, R.; Vale, M.J.; Saraiva, R. Land use and land cover changes in Zêzere watershed (Portugal)-Water quality implications. Sci. Total Environ. 2015, 527, 439-447. [CrossRef]

61. Khan, K.; Lu, Y.; Saeed, M.A.; Bilal, H.; Sher, H.; Khan, H.; Ali, J.; Wang, P.; Uwizeyimana, H.; Baninla, Y.; et al. Prevalent fecal contamination in drinking water resources and potential health risks in Swat, Pakistan. J. Environ. Sci. 2018, 72, 1-12. [CrossRef]

62. Oguntoke, O.; Aboderin, O.J.; Bankole, A.M. Association of water-borne diseases morbidity pattern and water quality in parts of Ibadan City, Nigeria. Tanzan. J. Health Res. 2009, 11, 189-195. [CrossRef] 
63. Ohene-Adjei, K.; Kenu, E.; Bandoh, D.A.; Addo, P.N.O.; Noora, C.L.; Nortey, P.; Afari, E.A. Epidemiological link of a major cholera outbreak in Greater Accra region of Ghana, 2014. BMC Public Health 2017, 17, 1-10. [CrossRef] [PubMed]

64. Quarcoo, G.; Hodgson, I.O.A.; Ampofo, J.A.; Cobbina, S.J.; Koku, J.E. Assessment of quality of drinking water in Amasaman, Accra (Ghana). J. Appl. Sci. Technol. 2015, 19, 38-43.

65. Webster, J.P.; Gower, C.M.; Knowles, S.C.L.; Molyneux, D.H.; Fenton, A. One health-an ecological and evolutionary framework for tackling Neglected Zoonotic Diseases. Evol. Appl. 2016, 9, 313-333. [CrossRef] [PubMed]

66. Grimes, J.E.T.; Tadesse, G.; Mekete, K.; Wuletaw, Y.; Gebretsadik, A.; French, M.D.; Harrison, W.E.; Drake, L.J.; Gardiner, I.A.; Yard, E.; et al. School Water, Sanitation, and Hygiene, Soil-Transmitted Helminths, and Schistosomes: National Mapping in Ethiopia. PLoS Negl. Trop. Dis. 2016, 10, 1-21. [CrossRef] [PubMed]

67. Laurent, J.S.; Mazumder, A. Influence of seasonal and inter-annual hydro- meteorological variability on surface water fecal coliform concentration under varying land-use composition. Water Res. 2013, 48, 170-178. [CrossRef] [PubMed]

68. Grimm, N.B.; Foster, D.; Groffman, P.; Grove, J.M.; Hopkinson, C.S.; Nadelhoffer, K.J.; Pataki, D.E.; Peters, D.P.C. The changing landscape: Ecosystem responses to urbanization and pollution across climatic and societal gradients. Front. Ecol. Environ. 2008, 6, 264-272. [CrossRef]

69. Li, Y.L.; Liu, K.; Li, L.; Xu, Z.X. Relationship of land use/cover on water quality in the Liao River basin, China. Procedia Environ. Sci. 2012, 13, 1484-1493. [CrossRef]

70. Kistemann, T.; Rind, E.; Koch, C.; Claßen, T.; Lengen, C.; Exner, M.; Rechenburg, A. Effect of sewage treatment plants and diffuse pollution on the occurrence of protozoal parasites in the course of a small river. Int. J. Hyg. Environ. Health 2012, 215, 577-583. [CrossRef]

71. Halstead, N.T.; Hoover, C.M.; Arakala, A.; Civitello, D.J.; De Leo, G.A.; Gambhir, M.; Johnson, S.A.; Jouanard, N.; Loerns, K.A.; McMahon, T.A.; et al. Agrochemicals increase risk of human schistosomiasis by supporting higher densities of intermediate hosts. Nat. Commun. 2018, 9, 1-10. [CrossRef]

72. Attua, E.M.; Ayamga, J.; Pabi, O. International Journal of River Basin Management Relating land use and land cover to surface water quality in the Densu River basin, Ghana Relating land use and land cover to surface water quality in the Densu River basin. Int. J. River Basin Manag. 2014, 12, 57-68. [CrossRef]

73. Aglanu, L.M.; Appiah, D.O. The Korle Lagoon in Distress: The Stress of Urban Solid Waste on Water Bodies in Accra, Ghana. Int. J. Innov. Appl. Stud. Issn 2014, 7, 2028-9324.

74. Chen, Q.; Mei, K.; Dahlgren, R.A.; Wang, T.; Gong, J.; Zhang, M. Science of the Total Environment Impacts of land use and population density on seasonal surface water quality using a modi fi ed geographically weighted regression. Sci. Total Environ. 2016, 572, 450-466. [CrossRef] [PubMed]

75. Lindblade, K.A.; Walker, E.D.; Onapa, A.W.; Katungu, J.; Wilson, M.L. Land use change alters malaria transmission parameters by modifying temperature in a highland area of Uganda. Trop. Med. Int. Health 2000, 5, 263-274. [CrossRef] [PubMed]

76. Anyona, D.N.; Matano, A.; Abuom, P.O.; Adoka, S.O.; Ouma, C.; Kanangire, C.K.; Owuor, P.O.; Ofulla, A.V.O. Distribution and abundance of schistosomiasis and fascioliasis host snails along the Mara River in Kenya and Tanzania. Infect. Ecol. Epidemiol. 2014, 1, 1-7.

77. Head, J.R.; Chang, H.; Li, Q.; Hoover, C.M.; Wilke, T.; Clewing, C.; Carlton, E.J.; Liang, S.; Lu, D.; Zhong, B.; et al. Genetic Evidence of Contemporary Dispersal of the Intermediate Snail Host of Schistosoma japonicum: Movement of an NTD Host Is Facilitated by Land Use and Landscape Connectivity. PLoS Negl. Trop. Dis. 2016, 10, 1-16. [CrossRef]

78. Zhang, Z.; Chen, Y.; Wang, P.; Shuai, J.; Tao, F.; Shi, P. River discharge, land use change, and surface water quality in the Xiangjiang River, China. Hydrol. Process. 2014, 28, 4130-4140. [CrossRef]

79. Tong, S.T.Y.; Chen, W. Modeling the relationship between land use and surface water quality. J. Environ. Manag. 2002, 66, 377-393. [CrossRef]

80. Alvani, J.; Boustani, F.; Tabiee, O.; Hashemi, M. The effects of human activity in yasuj area on the health of stream city. World Acad. Sci. Eng. Technol. 2011, 50, 341-345.

81. Jacob, P.; Henry, A.; Meheut, G.; Charni-ben-tabassi, N.; Ingrand, V.; Helmi, K. Health Risk Assessment Related to Waterborne Pathogens from the River to the Tap. Int. J. Environ. Res. Public Health 2015, 12, 2967-2983. [CrossRef] 
82. Cunha, D.G.F.; Sabogal-Paz, L.P.; Dodds, W.K. Land use influence on raw surface water quality and treatment costs for drinking supply in São Paulo State (Brazil). Ecol. Eng. 2016, 94, 516-524. [CrossRef]

83. Ciddio, M.; Mari, L.; Sokolow, S.H.; De Leo, G.A.; Casagrandi, R.; Gatto, M. The spatial spread of schistosomiasis: A multidimensional network model applied to Saint-Louis region, Senegal. Adv. Water Resour. 2017, 108, 406-415. [CrossRef] [PubMed]

84. Codjoe, S.N.A.; Larbi, R.T. Climate change/variability and schistosomiasis transmission in Ga district, Ghana. Clim. Dev. 2016, 8, 58-71. [CrossRef]

85. Picquet, M.; Ernould, J.C.; Vercruysse, J.; Southgate, V.R.; Mbaye, A.; Sambou, B.; Niang, M.; Rollinson, D. The epidemiology of human schistosomiasis in the Senegal River basin. Trans. R. Soc. Trop. Med. Hyg. 1996, 90, 340-346. [CrossRef]

86. Wang, T.P.; Johansen, M.V.; Zhang, S.Q.; Wang, F.F.; Wu, W.D.; Zhang, G.H.; Pan, X.P.; Yang, J.; Ørnbjerg, N. Transmission of Schistosoma japonicum by humans and domestic animals in the Yangtze River valley, Anhui province, China. Acta Trop. 2005, 96, 198-204. [CrossRef]

87. Johnson, E.S. Ecological Systems and Complexity Theory: Toward an Alternative Model of Accountability in Education. Complicity Int. J. Complex. Educ. 2008, 5, 1-10.

88. Alexander, K.A.; Heaney, A.K.; Shaman, J. Hydrometeorology and flood pulse dynamics drive diarrheal disease outbreaks and increase vulnerability to climate change in surface-water-dependent populations: A retrospective analysis. PLoS Med. 2018, 15, 1-25. [CrossRef]

89. Ahmed, A. GIS and Remote Sensing for Malaria Risk Mapping, Ethiopia. Isprs Int. Arch. Photogramm. Remote Sens. Spat. Inf. Sci. 2014, 40, 155-161. [CrossRef]

90. Tetteh-quarcoo, P.B.; Attah, S.K.; Donkor, E.S.; Nyako, M.; Minamor, A.A.; Afutu, E.; Hervie, E.T.; Ayeh-kumi, P.F. Urinary Schistosomiasis in Children-Still a Concern in Part of the Ghanaian Capital City. Open J. Med. Microbiol. 2013, 3, 151-158. [CrossRef]

91. Angelo, T.; Buza, J.; Kinung'Hi, S.M.; Kariuki, H.C.; Mwanga, J.R.; Munisi, D.Z.; Wilson, S. Geographical and behavioral risks associated with Schistosoma haematobium infection in an area of complex transmission. Parasites Vectors 2018, 11, 1-9. [CrossRef]

92. Chadeka, E.A.; Nagi, S.; Sunahara, T.; Cheruiyot, N.B.; Bahati, F.; Ozeki, Y.; Inoue, M.; Osada-Oka, M.; Okabe, M.; Hirayama, Y.; et al. Spatial distribution and risk factors of Schistosoma haematobium and hookworm infections among schoolchildren in Kwale, Kenya. PLoS Negl. Trop. Dis. 2017, 11, 1-17. [CrossRef]

93. World Health Organization. Making a Difference: Indicators to Improve Children's Environmental Health/prepared by David Briggs; World Health Organization: London, UK, 2003.

94. Ding, J.; Jiang, Y.; Fu, L.; Liu, Q.; Peng, Q.; Kang, M. Impacts of Land Use on Surface Water Quality in a Subtropical River Basin: A Case Study of the Dongjiang River Basin, Southeastern China. Water 2015, 7, 4427-4445. [CrossRef]

95. Gabiri, G.; Leemhuis, C.; Diekkrüger, B.; Näschen, K.; Steinbach, S.; Thonfeld, F. Modelling the impact of land use management on water resources in a tropical inland valley catchment of central Uganda, East Africa. Sci. Total Environ. 2019, 653, 1052-1066. [CrossRef] [PubMed]

96. Marale, S.M.; Mahajan, D.M.; Gavali, R.S.; Roa, K.R. Evaluation of Water Quality with Waterborne Diseases for Assessing Pilgrimage Impact along. Int. J. Environ. Prot. 2012, 2, 8-14.

97. World Health Organization Country Office. Ghana Situation: Report on Cholera Outbreak in Ghana; World Health Organizatio: Geneva, Switzerland, 2014; Volume 2015, pp. 1-4.

(C) 2020 by the authors. Licensee MDPI, Basel, Switzerland. This article is an open access article distributed under the terms and conditions of the Creative Commons Attribution (CC BY) license (http://creativecommons.org/licenses/by/4.0/). 